\title{
Edge Effects of Oil Pipeline Canopy Openings on Tree Community Structure and Dynamics in a Montane Atlantic Forest
}

\author{
Pablo J. F. Pena Rodrigues*, Leticia R. Melo, Rodolfo C. R. de Abreu, Mariana A. Iguatemy \\ Instituto de Pesquisas Jardim Botanico do Rio de Janeiro, Rio de Janeiro-RJ, Brazil \\ Email: "pablojfpr@hotmail.com, leticiamelo@gmail.com, rodolfodeabreu@gmail.com, \\ m_iguatemy@hotmail.com
}

Received 21 June 2016; accepted 22 July 2016; published 25 July 2016

Copyright (C) 2016 by authors and Scientific Research Publishing Inc.

This work is licensed under the Creative Commons Attribution International License (CC BY).

http://creativecommons.org/licenses/by/4.0/

\section{(c) (i) Open Access}

\begin{abstract}
The Atlantic forest has historically been severely deforested, and only fragments currently remain that are subject to a wide variety of anthropogenic impacts, including edge effects that can cause structural and functional degradation. The Tinguá Biological Reserve-RJ comprises approximately 26,000 hectares of well-preserved Atlantic Forest, but it is subject to impacts caused by two canopy openings along oil pipelines. Comparisons were made between pipeline edges and forest interiors to evaluate edge effects on the structure and dynamics of those tree communities. Tree densities were higher along forest edges, apparently increasing over time. Tree basal areas, on the other hand, have decreased along edges due to higher mortality rates. Linear canopy opening edges showed higher densities of small trees, while the interior had more very large trees, indicating changes in successional processes and community structural patterns due to edge effects.
\end{abstract}

\section{Keywords}

Fragmentation, Disturbance, Human-Modified Habitats, Linear Canopy Openings, Human Impact

\section{Introduction}

Fragmentation of tropical forests can promote edge effects that lead to accelerated increases in plant recruitment and mortality [1] [2]. Small forest fragments showed changes in their structure, increased density, and reduced

"Corresponding author.

How to cite this paper: Rodrigues, P.J.F.P., Melo, L.R., de Abreu, R.C.R. and Iguatemy, M.A. (2016) Edge Effects of Oil Pipeline Canopy Openings on Tree Community Structure and Dynamics in a Montane Atlantic Forest. Journal of Geoscience and Environment Protection, 4, 132-140. http://dx.doi.org/10.4236/gep.2016.47014 
biomass [3] [4], resulting in both local and regional extinctions of tree species [5] [6] and impoverished edge communities [12]. Some species, however, such as pioneer trees [7] and lianas [8], can be favored by the higher solar radiation levels found in disturbed sites, and show increases in recruitment and growth rates [9]. The structural and functional changes caused by edge effects are currently viewed as responsible for many of the major alterations seen in tropical forests [10].

The Atlantic Forest is the second largest forest type in Brazil, originally covering an area of 1.1 million km² and extending from the states of Rio Grande do Norte to Rio Grande do Sul [11] [12] although it is now reduced to only $11 \%$ of its original size [13]. This biome is counted among the 25 primary global "hotspots"-areas of high diversity and high concentrations of endemic species that are threatened by rapid habitat losses [14]. The ecological relationships between species have been severely altered in many tropical forests and their biological communities are at risk of extinction [15] due to deforestation, selective cutting, highway construction, and urban expansion [16], all leading to habitat loss and fragmentation [14] [17] [18].

These anthropogenic processes create mosaics of small forest remnants within urban or agricultural matrices [19], and increases in forest edges are followed by structural and functional changes in communities that arise from alterations of abiotic and biotic conditions [20] [21]. Increased light and wind flux near edges [22] can increase air temperatures and vapor pressure deficits, and decrease soil moisture levels [3], generating an edgeinterior microclimatic gradient. These changes invariably lead to negative biotic responses, including increased mortality, recruitment, damage, and tree falls [7] [8] [22].

While oil pipeline canopy openings represent a threat to tropical forests, they can also be viewed as potential large-scale field experiments [23], and we used such openings (created by two oil pipelines inside a protected area) to examine whether they create edge effects that impact the structures and dynamics of Brazilian montane Atlantic Forests.

\section{Material and Methods}

\subsection{Study Area}

The Tinguá Biological Reserve is located at Rio de Janeiro State, Brazil, and covers 26,000 hectares of preserved Atlantic Forest fragments $\left(22^{\circ} 28^{\prime}-39^{\prime} \mathrm{S} \times 43^{\circ} 13^{\prime}-34^{\prime} \mathrm{W}\right)$. The landscape there is rugged, with mountains intersected by river valleys. The climate is classified as Cwb (Köeppen), with temperatures ranging from $13^{\circ}$ to $23^{\circ} \mathrm{C}$, and average annual rainfall between $1500-2600 \mathrm{~mm}$. According to the classification proposed by [24], four vegetation types can be found in the reserve; submontane forests, montane forests, highland forests, and highland fields.

The local vegetation is relatively well-preserved, mainly because of the difficult access to the reserve, and its rivers supply water for part of Rio de Janeiro. Despite its importance, human impacts such as hunting and selective extraction are commonly observed (e.g., palm hearts-Euterpe edulis Mart), and two oil pipelines run through the area creating linear canopy openings [25], designated here as the Old Pipeline (OldP) and New Pipeline (NewP). The former was built following a very old (300 years) road, while the second was laid down approximately 40 years ago.

\subsection{Sampling Design and Comparisons}

To evaluate edge effects on the structures and dynamics of the tree communities, ten permanent plots $\left(300 \mathrm{~m}^{2}\right.$ per plot) were installed in each of three forest situations (treatments); along the edges of the Old Pipeline (OldP) and the New Pipeline (NewP), and in the forest interior (more than 400 meters from any edge). All of the trees with diameters at breast height $\geq 5 \mathrm{~cm}$ (hereafter DBH) inside each plot were tagged and their diameters measured in 2003, 2004 and 2005.

To verify whether the treatments differed in terms of their tree densities, basal areas, the numbers of dead trees, mortality, and recruitment, statistical comparisons were made between the treatment sites (OldP, NewP, and INT) using One-way ANOVA followed by the HSD Tukey test $(\mathrm{p}<0.05)$. The mean rates of mortality and recruitment were calculated using the formula $\mathrm{m}=1-\left(\mathrm{N}_{1} / \mathrm{N}_{0}\right) 1 / \mathrm{t}$ and $\mathrm{r}=1-(1-\mathrm{nr} / \mathrm{Nt}) 1 / \mathrm{t}$ [42] [43]. Diameter distributions (DBH) were compared using Hierarchical two-way ANOVA (Nested plot in treatment) followed by the Tukey test $(p<0.05)$ [45]. Normality and homoscedasticity tests were performed and, when necessary, the data were $\log (x+1)$ or $\sin ^{-1}$ transformed (to percentage data) [44]. In some cases, we analyzed small trees $(5 \leq \mathrm{DBH}<10 \mathrm{~cm})$ and large trees $(\mathrm{DBH} \geq 10 \mathrm{~cm})$ separately to sharpen comparisons using ANOVA. 


\section{Results}

The tree densities per hectare (n. ha ${ }^{-1}$ ) (2004/2005) were 1853/1857 in the forest interior (INT) and 2136/2173 and 2353/2380 along the edges of the Old Pipeline (OldP) and New Pipeline (NewP) respectively (Table 1). Thus, trees densities per plot were higher along the disturbance edges, with a significant difference mainly between the New Pipeline and the Interior in the years 2004 and 2005 ( $F=4.25 ; \mathrm{p}<0.02$ and $F=5.05$; $p<0.01$ respectively) (Figure 1). In 2005, the edges also showed more standing dead trees, with 5.5\% (OldP) and 6.6\%

Table 1. Densities and basal areas (BA) of trees (DBH $>5 \mathrm{~cm}$ ) per hectare in the years 2003, 2004 and 2005 in the Forest Interior, and along the Old Pipeline and New Pipeline in the Tinguá Biological Reserve, Rio de Janeiro State, Brazil.

\begin{tabular}{cccc}
\hline Treatment & Old pipeline & New pipeline & Interior \\
\hline Density $\left(\mathrm{ha}^{-1}\right)$ & & & 1796.7 \\
2003 & 2140.7 & 2206.7 & 1853.3 \\
2004 & 2136.7 & 2353.3 & 1856.7 \\
2005 & 2173.3 & 2380.0 & 49.7 \\
BA $\left(\mathrm{m}^{2} \cdot \mathrm{ha}^{-1}\right)$ & & & 50.5 \\
2003 & 51.1 & 49.7 & 51.3 \\
2004 & 50.0 & 47.3 & 47.8 \\
2005 & 50.8 & & 5 \\
\hline
\end{tabular}
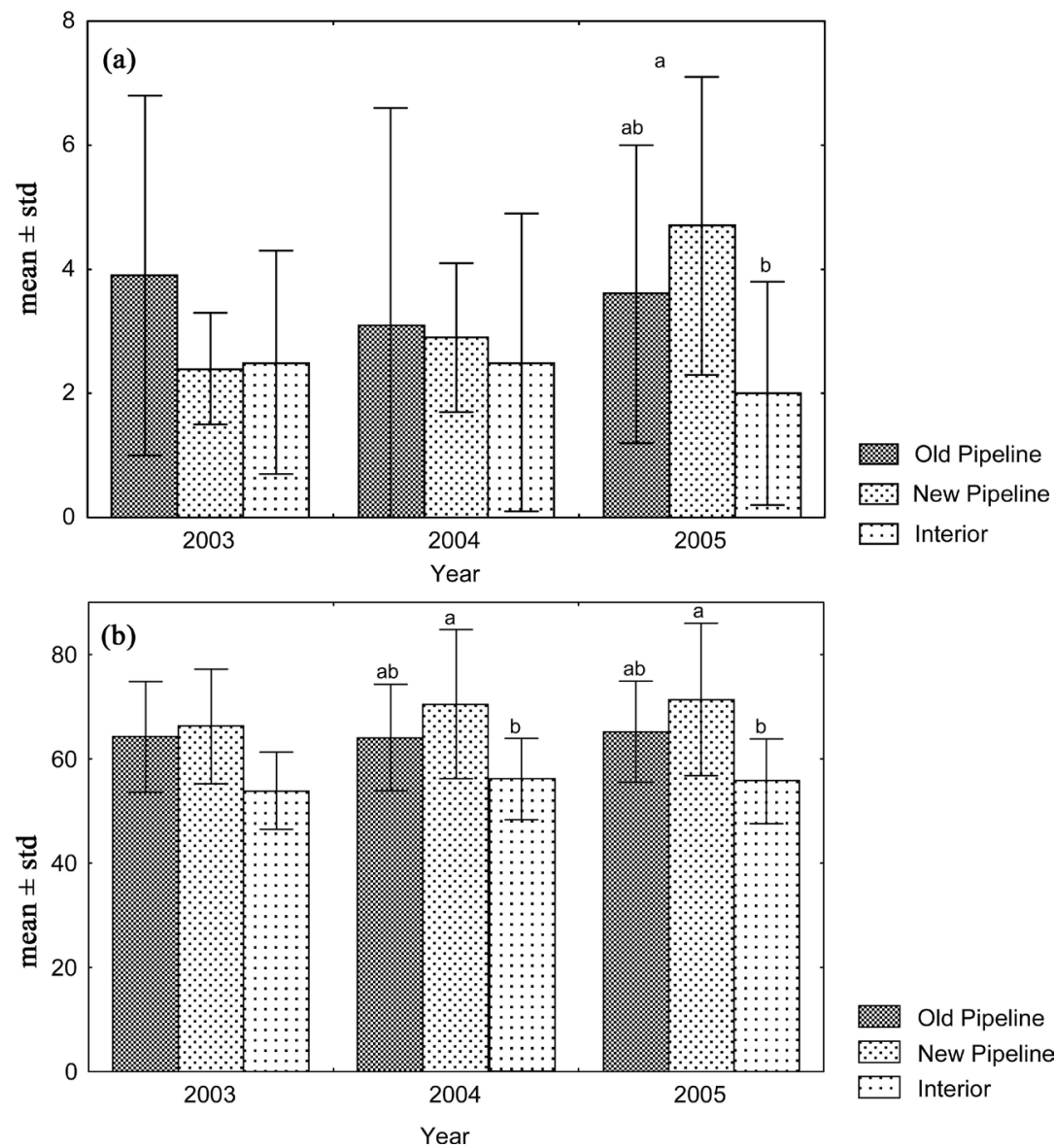

Figure 1. Standing dead trees density per plot (A) and live trees density per plot (B) and on the treatments forest Interior, Old Pipeline and New Pipeline at Tinguá Biological Reserve. Means ( \pm standard deviation) of density in the respective year followed by the same letter ( $a$ or $b)$ do not differ significantly ( $<<0.05$ ). 
(NewP) as opposed to $4 \%$ in the Interior (Figure 1). Surprisingly, no differences were found in terms of basal area between treatments during the study period.

Size structures considering all trees (DBH $\geq 5 \mathrm{~cm}$ ) did not differ between the treatments (Figure 2), although considering small trees $(5 \leq \mathrm{DBH}<10 \mathrm{~cm})$ and large trees $(\mathrm{DBH} \geq 10 \mathrm{~cm})$ separately showed distinct patterns. Small tree densities and basal areas per plot no showed differences between the treatments during the study years $(\mathrm{p}<0.05)$. Large tree densities were higher along the New Pipeline as compared to the Interior in the years 2004 and $2005(\mathrm{~F}=5.23, \mathrm{p}<0.01$ and $\mathrm{F}=4.83, \mathrm{p}<0.02$ respectively) (Table 2). Differences were observed between the Old Pipeline and the Interior in terms of the DBH values of small trees $(5 \leq \mathrm{DBH}<10 \mathrm{~cm})$ in 2003 and $2004(\mathrm{~F}=3.52, \mathrm{p}<0.03$ and $\mathrm{F}=4.33, \mathrm{p}<0.01)$, and in 2005 both edges were different from the Interior ( $\mathrm{F}$ $=4.93, \mathrm{p}<0.007$ ), (Table 2) with the latter having higher values. The same pattern was observed for the size structures of the large trees, with the interior site having higher values than the New Pipeline in the years 2004 and $2005(\mathrm{~F}=3.96, \mathrm{p}<0.02$ and $\mathrm{F}=3.42, \mathrm{p}<0.03$ ) (Table 2). Tree densities along the New Pipeline were higher, however, mainly in terms of the size classes $10-20,20-30$, and $30-40 \mathrm{~cm}$, while the densities of very large trees (diameters $>40 \mathrm{~cm}$ ) were always higher in the Interior (Figure 2).

Vegetation dynamics along the edges were more accelerated as compared to the interior, principally along the New Pipeline. Despite the general pattern of recruitment of new individuals between the years 2003-2005 (Old Pipeline: 1.5\%; New Pipeline: 7.28\%, and Interior: 3.23\%), the edges showed reduced basal areas (Old Pipeline: $-0.59 \%$; New Pipeline: $-3.97 \%$ ) while Interior gained less basal area (3.12\%). Furthermore, New Pipeline mortality rates were higher and differed significantly from the interior site during the period from 2004-2005 (Figure 3).

Edge effects can also be detected by observing the occurrence of individuals with multiple trunks, and higher frequencies of these individuals were seen along the edges (Figure 4). On the other hand, the palm tree Euterpe edulis exhibited strong reductions in numbers along forest edges.

\section{Discussion}

Edge effects due to disturbance regimes can cause profound changes in species interactions and resource

Old Pipeline

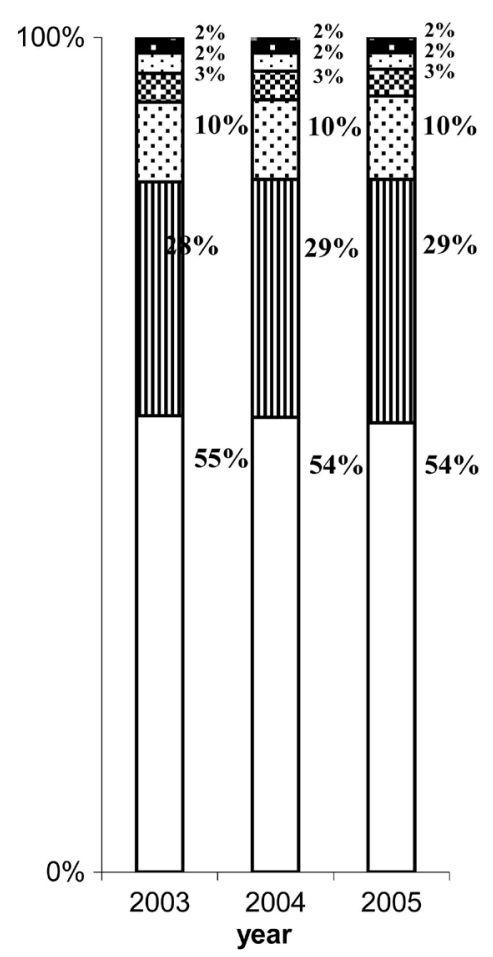

New Pipeline

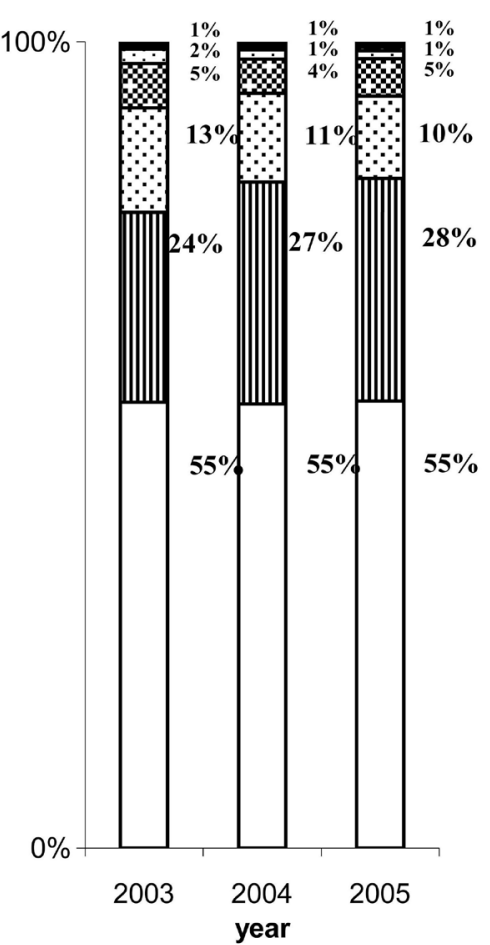

Interior

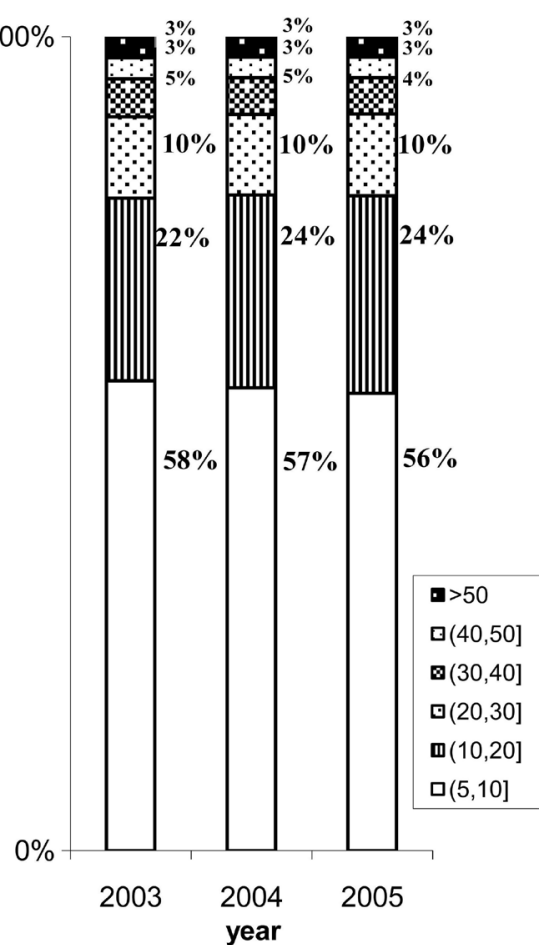

Figure 2. Trees frequency diameter distributions (\%) on the treatments forest Interior, Old Pipeline and New Pipeline in six DBH (cm) classes at Tinguá Biological Reserve in the years 2003, 2004 and 2005. 
Table 2. Comparisons between the communities of small trees $(5 \leq \mathrm{DBH}<10 \mathrm{~cm})$ and large trees $(\mathrm{DBH} \geq 10 \mathrm{~cm})$ in the Forest Interior, and along the Old Pipeline and New Pipeline at the Tinguá Biological Reserve, Rio de Janeiro State, Brazil. The marked ( $\left(^{*}\right)$ F values indicate significant differences between treatments. Density means ( \pm standard deviation) (n), basal areas (BA) and diameters (DBH) followed by the same letter (a or b, on the same lines) do not differ significantly (Tukeytype test, $\mathrm{p}<0.05)$.

\begin{tabular}{|c|c|c|c|c|}
\hline Treatment & Old pipeline & New pipeline & Interior & ANOVA (One-Way or Two-Way) \\
\hline \multicolumn{5}{|l|}{ Small trees } \\
\hline n 2003 & $37.8 \pm 9.0$ & $37.2 \pm 11.2$ & $31.3 \pm 7.9$ & $\mathrm{~F}(2,21)=0.93 ; \mathrm{p}<0.4106$ \\
\hline n 2004 & $35.9 \pm 8.2$ & $39.6 \pm 12.3$ & $32.1 \pm 8.7$ & $\mathrm{~F}(2,27)=1.44 ; \mathrm{p}<0.2536$ \\
\hline n 2005 & $35.7 \pm 8.1$ & $40.5 \pm 13.8$ & $31.8 \pm 8.3$ & $\mathrm{~F}(2,27)=1.76 ; \mathrm{p}<0.1911$ \\
\hline BA 2003 & $0.14 \pm 0.04$ & $0.15 \pm 0.05$ & $0.13 \pm 0.04$ & $\mathrm{~F}(2,21)=0.42 ; \mathrm{p}<0.6621$ \\
\hline BA 2004 & $0.14 \pm 0.04$ & $0.16 \pm 0.06$ & $0.14 \pm 0.04$ & $\mathrm{~F}(2,27)=0.79 ; \mathrm{p}<0.4652$ \\
\hline BA 2005 & $0.15 \pm 0.04$ & $0.17 \pm 0.06$ & $0.14 \pm 0.04$ & $\mathrm{~F}(2,27)=0.90 ; \mathrm{p}<0.4202$ \\
\hline DBH 2003 & $7.0 \pm 1.4^{\mathrm{a}}$ & $7.1 \pm 1.4^{\mathrm{ab}}$ & $7.3 \pm 1.4^{\mathrm{b}}$ & $F(2,797)=3.52^{*} ; p<0.0301$ \\
\hline DBH 2004 & $7.0 \pm 1.4^{\mathrm{a}}$ & $7.1 \pm 1.4^{\mathrm{ab}}$ & $7.4 \pm 1.5^{\mathrm{b}}$ & $\mathrm{F}(2,1041)=4.33^{*} ; \mathrm{p}<0.0134$ \\
\hline DBH 2005 & $7.1 \pm 1.4^{\mathrm{a}}$ & $7.2 \pm 1.4^{\mathrm{a}}$ & $7.5 \pm 1.4^{\mathrm{b}}$ & $F(2,1050)=4.93^{*} ; p<0.0074$ \\
\hline \multicolumn{5}{|l|}{ Big trees } \\
\hline n 2003 & $28.4 \pm 5.7$ & $29.0 \pm 4.3$ & $22.6 \pm 6.3$ & $F(2,21)=3.26 ; p<0.0583$ \\
\hline n 2004 & $28.7 \pm 5.5^{\mathrm{ab}}$ & $31.0 \pm 4.8^{\mathrm{a}}$ & $23.5 \pm 5.5^{\mathrm{b}}$ & $\mathrm{F}(2,27)=5.23^{*} ; \mathrm{p}<0.0121$ \\
\hline n 2005 & $29.5 \pm 5.8^{\mathrm{ab}}$ & $30.9 \pm 4.8^{\mathrm{a}}$ & $23.9 \pm 5.3^{\mathrm{b}}$ & $\mathrm{F}(2,27)=4.83^{*} ; \mathrm{p}<0.0161$ \\
\hline BA 2003 & $1.4 \pm 0.3$ & $1.3 \pm 0.4$ & $1.4 \pm 0.3$ & $F(2,21)=0.05 ; p<0.9480$ \\
\hline BA 2004 & $1.4 \pm 0.4$ & $1.3 \pm 0.3$ & $1.4 \pm 0.3$ & $\mathrm{~F}(2,27)=0.40 ; \mathrm{p}<0.6741$ \\
\hline BA 2005 & $1.4 \pm 0.4$ & $1.3 \pm 0.3$ & $1.4 \pm 0.3$ & $\mathrm{~F}(2,27)=0.46 ; \mathrm{p}<0.6375$ \\
\hline DBH 2003 & $20.1 \pm 1.6$ & $21.1 \pm 1.5$ & $21.7 \pm 1.63$ & $F(2,603)=2.08 ; p<0.1256$ \\
\hline DBH 2004 & $19.8 \pm 1.6^{\mathrm{ab}}$ & $19.4 \pm 1.5^{\mathrm{a}}$ & $21.3 \pm 1.63^{\mathrm{b}}$ & $F(2,802)=3.96^{*} ; p<0.0194$ \\
\hline DBH 2005 & $19.7 \pm 1.6^{\mathrm{ab}}$ & $19.4 \pm 1.5^{\mathrm{a}}$ & $21.0 \pm 1.64^{\mathrm{b}}$ & $\mathrm{F}(2,813)=3.42^{*} ; \mathrm{p}<0.0331$ \\
\hline
\end{tabular}
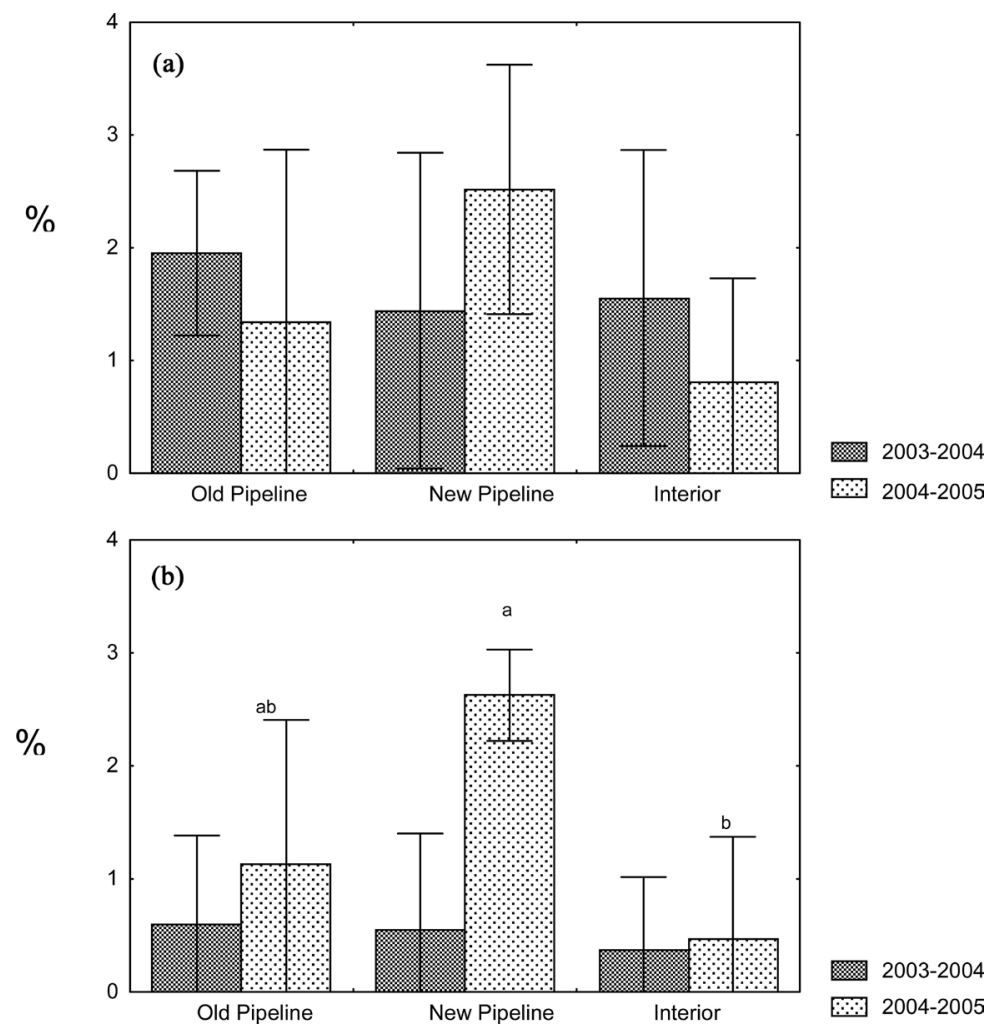

Figure 3. Recruitment (a) and mortality (b) annual rates on the treatments forest Interior, Old Pipeline and New Pipeline at Tinguá Biological Reserve in the periods 2003-2004 and 2004-2005. Treatments with means ( \pm standard deviation) followed by the same letter $(\mathrm{a}$ or $\mathrm{b})$ do not differ $(\mathrm{p}<0.05)$. 


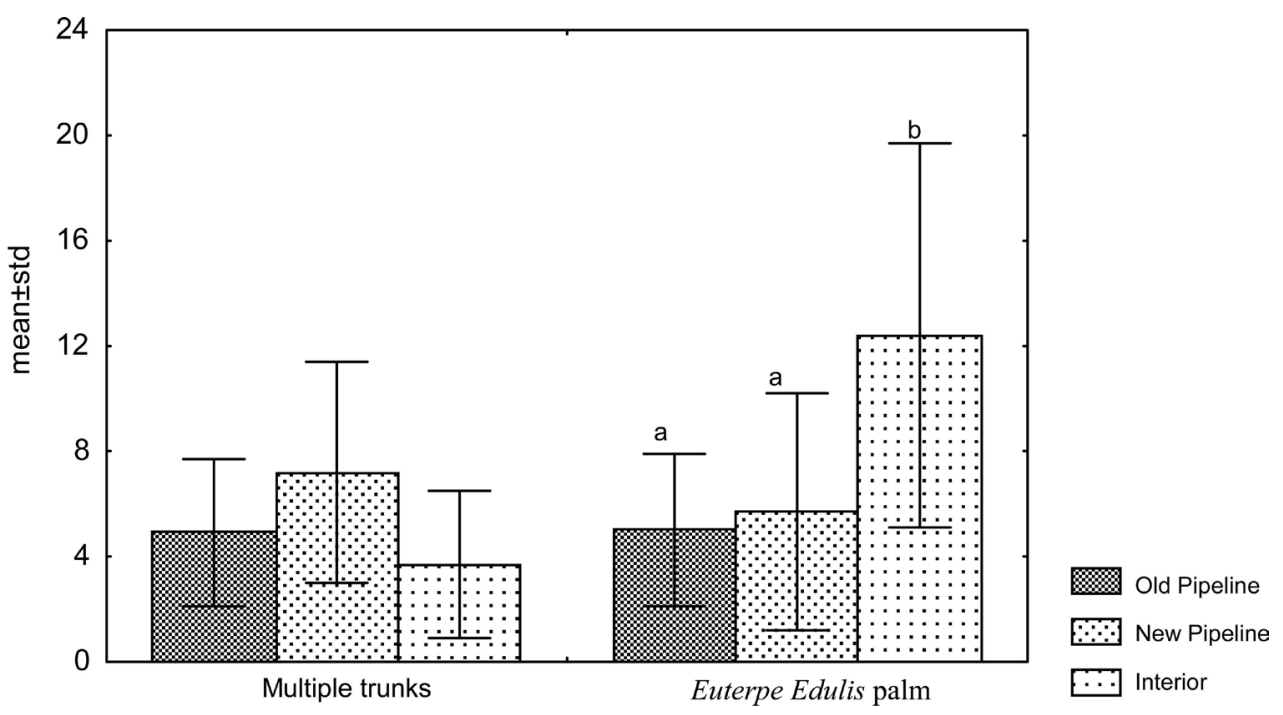

Figure 4. Density of multiple trunks and Euterpe edulis palm per plot on the treatments forest Interior, Old Pipeline and New Pipeline at Tinguá Biological Reserve in the year 2005. Means ( \pm standard deviation) of density followed by the same letter ( $\mathrm{a}$ or $\mathrm{b})$ do not differ significantly $(\mathrm{p}<0.05)$.

availability [4] [5] [7] [8] often leading to increases in mortality, recruitment, biotic damage, and tree falls [7] [8] [22], and tropical forests subjected to edge effects often remain in early-successional stages [15] [26] [27]. Tree structures and their dynamics indicated that the forest communities in the Tinguá Biological Reserve were subject to edge effects, especially along the edge of the most recently installed pipeline.

Tree densities increased over the years, and were highest along the pipeline, due to greater light availability, which generally favors recruitment [28]. Canopy openness near edges (with increased wind and light flux) can therefore favor recruitment, mortality [7] [8] [28] and the growth of small plants and/or juveniles [29]. Their observed mortality and recruitment rates were similar, however, to other Tropical Forests [12] [30] [31]. Some tropical forests lose from $15 \%$ to $35 \%$ of their biomass due to increased mortality in the first 5 - 10 years after fragmentation [32]. In the case of Tinguá Biological Reserve, the expected decrease in basal area was observed only along pipeline edges during the period from 2003-2005 (Old Pipeline: $-0.59 \%$, New Pipeline: $-3.97 \%$, Interior: $+3.12 \%$, Table 1 ).

Therefore, increases in the numbers of small pioneer trees [28] [33] [34] and changes in successional patterns due to edge effects [5] [35] resulted in higher densities of small trees along the forest edges. As small plants are generally more fragile and may exhibit higher mortality rates [36] [37] vegetation dynamics will often be accelerated along edges. Additionally, very large trees may be excluded depending on the disturbance scale and intensity [8] [15], which would explain why very large trees were only found in the Interior.

Edge effects may be attenuated over time [5], however, by the buffering effects of new vegetation originating at the edge [19], or by the establishment of certain vegetation communities such as vines and bamboos [38] along those disturbed areas [7] [12] [39] [40]. The oldest edge (Old Pipeline) was found to be more similar to the interior. The maintenance of abrupt edges and the proximity of shrubby or herbaceous matrices, however, can favor continuing anthropogenic impacts [40] [41]. Linear canopy openings may be less harmful, than fire-prone sites and agricultural fields, although they can facilitate the entry of hunters and collectors. The lower edge densities of the heart-palm Euterpe edulis (pers. observation) is related to illegal extraction and numerous cut trunks were observed during the course of the fieldwork.

\section{Conclusion}

Tree densities were higher along forest edges while tree basal areas decreased along edges due to higher mortality rates. On the other hand, edges showed higher densities of small trees, while the interior had more very large trees. Furthermore, pipelines can also favor the anthropogenic damage by providing access to hunters and collectors. Thus, these linear canopy openings promote edge effects, although they seem to be less detrimental than edges on fire-prone sites and agricultural fields. 


\section{Acknowledgements}

We thank Haroldo Lima, Sebastião Neto, Rejan Guedes-Bruni, Flavio Ramos and Andrea Costa for comments made on an earlier version of this work; Walter da Silva and Adilson Pintor for their help during the fieldwork; two anonymous referees by their corrections; the Fundação Flora and PETROBRAS for financial support (research grant number 6000.0023998.06.02 to Programa Mata Atlântica); the Instituto Chico Mendes de Conservação da Biodiversidade (ICMBio) and Colonia de Férias dos Aeroviários for providing logistical support; Mr. Roy Funch for linguistic advice.

\section{References}

[1] Malcon, J.R. (1994) Edge Effects in Central Amazonia Forest Fragments. Ecology, 75, 2438-2445. http://dx.doi.org/10.2307/1940897

[2] Laurance, W.F., Lovejoy, T.E., Vasconcelos, H.L., Bruna, E.M., Didham, R.K., Stouffer, P.C., Gascon, C., Bierregaard, R.O., Laurance, S.G. and Sampaio, E. (2002) Ecosystem Decay of Amazonian Forest Fragments: A 22-Year Investigation. Conservation Biology, 13, 605-618. http://dx.doi.org/10.1046/j.1523-1739.2002.01025.x

[3] Kapos, V., Wandelli, E., Camargo, J.L. and Ganade, G. (1997) Edge-Related Changes in Environment and Plant Responses Due to Forest Fragmentation in Central Amazonia. In: Laurance, W.F. and Bierregaard-Jr., R.O., Eds., Tropical Forest Remnants: Ecology, Management, and Conservation of Fragmented Communities, Chicago University Press, Chicago, 33-44.

[4] Ries, L., Fletcher, R.J., Battin, J. and Sisk, T.D. (2004) Ecological Responses to Habitat Edges. Annual Review of Ecology and Systematics, 35, 491-522. http://dx.doi.org/10.1146/annurev.ecolsys.35.112202.130148

[5] Saunders, D.A., Hobbs, R.J. and Margules, C.R. (1991) Biological Consequences of Ecosystem Fragmentation: A Review. Conservation Biology, 5, 18-32. http://dx.doi.org/10.1111/j.1523-1739.1991.tb00384.x

[6] Tabarelli, M., Silva, J.M.C. and Gascon, C. (2004) Forest Fragmentation, Synergisms and the Impoverishment of Neotropical Forests. Biological Conservation, 13, 1419-1425.

[7] Laurance, W.F., Ferreira, L.V., Rankin deMerona, J.M. and Laurance, S.G. (1998) Rain Forest Fragmentation and the Dynamics of Amazonian Tree Communities. Ecology, 79, 2032-2040. http://dx.doi.org/10.1890/0012-9658(1998)079[2032:RFFATD]2.0.CO;2

[8] Laurance, W.F. (2000) Do Edge Effects Occur over Large Spatial Scales? Trends in Ecology and Evolution, 15, 134135. http://dx.doi.org/10.1016/S0169-5347(00)01838-3

[9] Sizer, N. and Tanner, E.V.J. (1999) Responses of Woody Plant Seedlings to Edge Formation in a Lowland Tropical Rainforest, Amazonia. Biological Conservation, 91, 135-142. http://dx.doi.org/10.1016/S0006-3207(99)00076-2

[10] Laurence, W.F. and Bierregaard, R.O. (1997) Tropical Forest Remnants; Ecology, Management and Conservation of Fragmented Communities. Chicago University Press, Chicago.

[11] Rizzini, C.T. (1997) Tratado de Fitogeografia do Brasil: Aspectos ecológicos, sociológicos e florísticos. Âmbito Cultural Edições, Rio de Janeiro.

[12] Oliveira-Filho, A.T., Mello, J.M. and Scolforo, J.R.S. (1997) Effects of Past Disturbance and Edges on Tree Community Structure and Dynamics within a Fragment of Tropical Semideciduous Forest in South-Eastern Brazil. Plant Ecology, 131, 45-66. http://dx.doi.org/10.1023/A:1009744207641

[13] Ribeiro, M.C., Metzger, J.P., Martensen, A.C., Ponzoni F.J. and Hirota, M.M. (2009) The Brazilian Atlantic Forest: How Much Is Left, and How Is the Remaining Forest Distributed? Implications for Conservation. Biological Conservation, 142, 1141-1153. http://dx.doi.org/10.1016/j.biocon.2009.02.021

[14] Myers, N., Mittermeier, R.A., Mittermeier, C.G., Fonseca, G.A.B. and Kent, J. (2000) Biodiversity Hotspots for Conservation Priorities. Nature, 403, 853-858. http://dx.doi.org/10.1038/35002501

[15] Laurance, W.F., Nascimento, H.M.E., Laurance, S.G., Andrade, A., Ewers, R.M., Harms, K.E., Luizão, R.C.C. and Ribeiro, J.E. (2007) Habitat Fragmentation, Variable Edge Effects and the Landscape-Divergent Hypothesis. PLoS ONE, 2, 1017. http://dx.doi.org/10.1371/journal.pone.0001017

[16] Dean, W. (2002) A ferro e fogo: A história da devastação da Mata Atlântica brasileira. Companhia das Letras, São Paulo.

[17] Morellato, L.P.C. and Haddad, C.F.B. (2000) Introduction: The Brazilian Atlantic Forest. Biotropica, 32, 786-792. http://dx.doi.org/10.1111/j.1744-7429.2000.tb00618.x

[18] Rodrigues, P. J. F. P. and Nascimento, M.T. (2006) Fragmentação florestal: breves considerações teóricas sobre efeitos de borda. Rodriguésia, 57, 63-74. 
[19] Harris, L.D. (1984) The Fragmented Forest. Chicago University Press, Chicago.

[20] Bierregaard, R.O., Lovejoy, T.E., Kapos, V., dos Santos, A.A. and Hutchings, R.W. (1992) The Biological Dynamics of Tropical Rainforest Fragments. BioScience, 42, 859-866. http://dx.doi.org/10.2307/1312085

[21] Harper, J.L. (1977) Population Biology of Plants. Academic Press, London.

[22] Lovejoy, T.E., Bierregaard Jr., R.O., Rylands, A.B., Malcon, J.R., Quintela, C.E., Harpe, L H., Brown Jr., K.S., Powell, A.H., Powell, G.V.N., Schubart, H.O.R. and Hays, M.B. (1986) Edge and Other Effects of Isolation on Amazon Forest Fragments. In: Soulé, M.E., Ed., Conservation Biology: The Science of Scarcity and Diversity, Sinauer Associates, Sunderland, 257-285.

[23] Prieto, P.V., Sansevero, J.B.B., Garbin, M.L., Braga, J.M.A. and Rodrigues, P.J.F.P. (2014) Edge Effects of Linear Canopy Openings on Understory Communities in a Lowland Atlantic Tropical Forest. Applied Vegetation Science, 17, 121-128. http://dx.doi.org/10.1111/avsc.12043

[24] Veloso, H.P., Rangel-Filho, A.L.R. and Lima, J.C.A. (1991) Classificação da vegetação brasileira, adaptada a um sistema universal. IBGE, Rio de Janeiro.

[25] Rodrigues, P.J.F.P., Iguatemy, M.A., Prieto P.V., Reis, T.S., Sansevero J.B.B. and Simões-Jesus, M.F. (2008) As pesquisas no longo prazo em parcelas permanentes do Jardim Botânico do Rio de Janeiro. In: Sanquetta, C.R., Ed., Experiências de monitoramento no Bioma Mata Atlântica com uso de parcelas permanentes, RedeMap Press, Curitiba, 47-80.

[26] Oliveira, M.A., Grillo, A.S. and Tabarelli, M. (2004) Forest Edge in the Brazilian Atlantic Forest, Drastic Changes in Tree Species Assemblages. Oryx, 38, 389-394. http://dx.doi.org/10.1017/S0030605304000754

[27] Tabarelli, M., Lopes, A.V. and Peres, C.A. (2008) Edge-Effects Drive Tropical Forest Fragments Towards an Early-Successional System. Biotropica, 40, 657-661. http://dx.doi.org/10.1111/j.1744-7429.2008.00454.x

[28] Laurance, W.F., Ferreira, L.V., Rankin de Merona, J.M., Laurance, S.G., Hutchings, R.W. and Lovejoy, T.E. (1998) Effects of Forest Fragmentation on Recruitment Patterns in Amazonian Tree Communities. Conservation Biology, 12, 460-464. http://dx.doi.org/10.1046/j.1523-1739.1998.97175.x

[29] Hubbell, S.P., Foster, R.B., O’Brien, S.T., Harms, K.E., Condit, R., Wechsler, B., Wright, S.J. and Loo de Lao, S. (1999) Light-Gap Disturbances, Recruitment Limitation, and Tree Diversity in a Neotropical Forest. Science, 283, 554557. http://dx.doi.org/10.1126/science.283.5401.554

[30] Lieberman, D., Lieberman, M., Peralta, R. and Harshtorn, G.S. (1985) Mortality Patterns and Stand Turnover Rates in Wet Tropical Forest in Costa Rica. Journal of Ecology, 73, 915-924. http://dx.doi.org/10.2307/2260157

[31] Harshtorn, G.S. (1990) An Overview of Neotropical Forest Dynamics. In: Gentry, A.H., Ed., Four Neotropical Rainforest, Yale University Press, London, 585-599.

[32] Laurance W.F., Ferreira, L.V., Gascon, C. and Lovejoy, T.E. (1998) Biomass Loss in Forets Fragments. Science, 282, 1610-1611.

[33] Budowski, G. (1965) Distribution of Tropical American Rain Forest Species in the Light of Successional Processes. Turrialba, 15, 40-42.

[34] Whitmore, T.C. (1989) Canopy Gaps and the Two Major Groups of Forest Trees. Ecology, 70, 536-538. http://dx.doi.org/10.2307/1940195

[35] Matlack, G.R. (1994) Vegetation Dynamics of the Forest Edge: Trends in Space and Successional Time. Journal of Ecology, 82, 113-123. http://dx.doi.org/10.2307/2261391

[36] Augspurger, C.K. (1984) Seedling Survival of Tropical Tree Species: Interactions of Dispersal Distance, Light-Gaps and Pathogens. Ecology, 65, 1705-1712. http://dx.doi.org/10.2307/1937766

[37] De Steven, D. (1997) Tropical Tree Seedling Dynamics: Recruitment Patterns and Their Population Consequences for Three Canopy Species in Panama. Journal of Tropical Ecology, 10, 369-383. http://dx.doi.org/10.1017/S0266467400008038

[38] Tabanez, A.A.J. and Viana, V.M. (2000) Patch Structure within Brazilian Atlantic Forest Fragments and Implications for Conservation. Biotropica, 32, 925-933. http://dx.doi.org/10.1646/0006-3606(2000)032[0925:PSWBAF]2.0.CO;2

[39] Camargo, J.L.C. and Kapos, V. (1995) Complex Edge Effects on Soil Moisture and Microclimates in Central Amazonia Forest. Journal of Tropical Ecology, 11, 205-221. http://dx.doi.org/10.1017/S026646740000866X

[40] Laurance, W.F., Lovejoy, T.E., Vasconcelos, H.L., Bruna, E.M., Didham, R.K., Stouffer, P.C., Gascon, C., Bierregaard, R.O., Laurance, S.G. and Sampaio, E. (2002) Ecosystem Decay of Amazonian Forest Fragments: A 22-Year Investigation. Conservation Biology, 13, 605-618. http://dx.doi.org/10.1046/j.1523-1739.2002.01025.x

[41] Gascon, C., Lovejoy, T.E., Bierregaard, R.O., Malcolm, J.R., Stouffer, P.C., Vasconcelos, H.L., Laurance, W.F., Zimmerman, B., Toucher, M. and Borges, S. (1991) Matrix Habitat Species Richness in Tropical Forest Remnants. Ecology, 91, 223-229. 
[42] Sheil, D. and May, R.M. (1996) Mortality and Recruitment Rate Evaluations in Heterogeneous Tropical Ecology. Journal of Ecology, 84, 91-100. http://dx.doi.org/10.2307/2261703

[43] Sheil, D., Jennings, S. and Savil, L.P. (2000) Long-Term Permanent Plot Observations of Vegetation Dynamics in Budongo, a Ugandan Rain Forest. Journal of Tropical Ecology, 16, 765-800. http://dx.doi.org/10.1017/S0266467400001723

[44] Zar, J. (1999) Biostatistical Analysis. 4th Edition, Prentice Hall, Englewood Cliffs.

[45] Sahai, H. and Ageel, M.I. (2000) The Analysis of Variance: Fixed, Random and Mixed Models. Birkhäuser, Boston. http://dx.doi.org/10.1007/978-1-4612-1344-4

Submit or recommend next manuscript to SCIRP and we will provide best service for you:

Accepting pre-submission inquiries through Email, Facebook, Linkedin, Twitter, etc A wide selection of journals (inclusive of 9 subjects, more than 200 journals)

Providing a 24-hour high-quality service

User-friendly online submission system

Fair and swift peer-review system

Efficient typesetting and proofreading procedure

Display of the result of downloads and visits, as well as the number of cited articles

Maximum dissemination of your research work

Submit your manuscript at: http://papersubmission.scirp.org/ 